\title{
Integrating activity-based costing with economic value added
}

\author{
Tandung Huynh ${ }^{1}$, Guangming Gong ${ }^{1}$, Anhtuan Nguyen $^{2}$ \\ ${ }^{1}$ Business School, Hunan University, China \\ ${ }^{2}$ Faculty of Accounting and Auditing in Industrial University of Hochiminh City, Vietnam
}

\section{Email address:}

huynhtandung_hnu@yahoo.com(T. Huynh)

\section{To cite this article:}

Tandung Huynh, Guangming Gong, Anhtuan Nguyen. Integrating Activity-Based Costing with Economic Value Added, Journal of Investment and Management. Vol. 2, No. 3, 2013, pp. 34-40. doi: 10.11648/j.jim.20130203.11

\begin{abstract}
Activity-Based Costing (ABC) was developed in the mid 1980s by Kaplan and it has been applied very popular in developed countries with obvious advantages. Although ABC system has more advantages than traditional costing (TC) system, but in today's competitive economic environment it has not met fulfilled provision of sufficient information for decision-making, especially single $\mathrm{ABC}$ method ignores capital cost. The lack of capital cost is the reason why some products have inaccurate product costs and as results of that they have profit under $\mathrm{ABC}$ method but when capital cost is charged to those products, they cause a loss because they consume high invest fund. Imprecise information provided by single $\mathrm{ABC}$ method to managers is the reason why managers make inaccurate decisions. How to overcome this limitation of $\mathrm{ABC}$ ? This paper researches on the integration of $\mathrm{ABC}$ with Economic Value Added (EVA ${ }^{\mathrm{TM}}$ ) as one way to overcome its limitation and innovation management accounting. Based on the data provided by Dong Su Company, this paper calculated profits of two customer groups using the new methodology (EVA-ABC) and also the old methodology (single ABC) to show how vague or inaccurate is the results you get when you use the old methodology and how accurate is the results you get when using the new methodology. The calculation showed that under EVA-ABC group 1 generates the value (13\%) for this company but group 2 reduces the value of the business and destroy its capital (-8\%). However under the single ABC method, the calculation showed that both two customer groups create profits for Dong Su with profit rate are $20 \%$ and $4 \%$ respectively which was incorrect.
\end{abstract}

Keywords: Integration, Activity Based Costing (ABC), Economic Value Added (EVA'M $)$, EVA-ABC Model

\section{Introduction}

In today's business environment, with high manufacturing technology, globalization markets, service industry growth, leads companies facing a fierce competition in domestic and global markets. To survive and develop, they must implement strategic management tools in order to increase their competitiveness and get more advantages. Most of management decisions are based on cost information. How to calculate and assign accurate costs to goods (products or services) in order to support flexible, accurate, timely, and reliable information for managers? The traditional system relies on functional-based costing and control lead to fail in support the required information for realizing competitive advantages. In a functional-based system, costing and cost control are centered on organization functions and it fails to provide information in detailed, accurate, timely, and reliable enough to support the requirement in today's business environment.

$\mathrm{ABC}$ has been perceived as a normal costing system by researchers, academic as well as accounting practitioners. It has also been believed as the most modern costing system that can use separately or integrate with current system to provide proper and confident information for decision-making. Although $\mathrm{ABC}$ has many advantages than traditional costing, however, in today's business, it also reveals many shortcomings such as it just focuses on operating costs, and ignores capital costs that need to produce goods and provide them to customers. In today's fiercely competitive business, in order to obtain competitive advantage, companies invest more and more capital in technology as well as the processes for providing services to customers. Therefore, capital cost is more and more significant proportion in total cost. Capital needed for processes or projects to produce different goods are substantially diverse. Ignoring capital cost lead to distort product cost information. An 
arbitrary capital cost allocation affects to provide information for cost control, planning and leads managers mistake in evaluating operating efficiency. Some of mistakes we can see: managers wrong in setting the selling price affecting to organization's competitive advantage and profitability; mistake in evaluating profitability of particular process or goods. In the prior literature, there were a lot of researches related to single $\mathrm{ABC}$ method (e.g. Cooper and Kaplan (1991), Hansen and Mowen (2003), Lewis (1992), Khozein (2011)) but little written about the integration of ABC with other management accounting method such as integrating $\mathrm{ABC}$ with standard costing, $\mathrm{ABC}$ with target costing, $\mathrm{ABC}$ with EVA in order to foster ABC and other method's advantages then create new value for users. To continue research on integration of $\mathrm{ABC}$ with other management accounting method for covering its shortcomings and creating a new decision-support method is necessary and imperativeness through that innovate management accounting. By integrating $\mathrm{ABC}$ with $\mathrm{EVA}^{\mathrm{TM}}$ generates new management method (EVA-ABC) for calculating and improving cost control and evaluating organization's operating efficiency is necessary is the main aim of this paper. In this paper, the methodology used is a type of theoretical mining and logical reasoning to explore the limitations of $\mathrm{ABC}$ and the components of EVA that can be used to overcome the shortcomings of ABC method.

\section{Overview ABC and EVA}

\subsection{Activity-Based Costing}

In global competition, business organizations have a little control of the selling price, especially in the developing countries and the less-developed countries, there are very few business organizations have the opportunity to control the selling price. Their products must be sold at the price available in the global market. To gain benefit and get more advantage competitiveness, they must control costs, reduce them and based on them to make right decision. Costs play a very important role in any organization. All activities generate cost, however in among of them there are a lot of activities not create value. To know value-added activities and non-value-added activities is a very important in today's management. TC in today's business environment reveals many shortcomings, its information does not meet management requirement. $\mathrm{ABC}$ is a modern costing method, it overcome the shortcoming of TC method and brings many advantages for businesses. To help the organizations definite value-added activities and non-value-added activities is the core of $\mathrm{ABC}$ system. In order to accomplish its mission, $\mathrm{ABC}$ must be assign accurately indirect cost to goods (products or services). By using multiple drivers to assign indirect cost, $\mathrm{ABC}$ has achieved its mission. Kaplan and Atkinson (1998) addressed that ABC developed to provide more - accurate ways of assigning the costs of indirect and support resources to activities, business process, products, services, and customers. The goal of $\mathrm{ABC}$ is not only to allocate common costs to products. Its goal is also to measure and then price out all the resources used for activities that support the production and delivery of products and service to customers.

Under ABC theory, activities consume resources and products consume activities. So in ABC model include two stages: in first stage cost of resource is assigned to activities by direct tracing or using driver tracing; in the second stage, cost of activities is assigned to products. The basic model of $\mathrm{ABC}$ system as follow, for example:

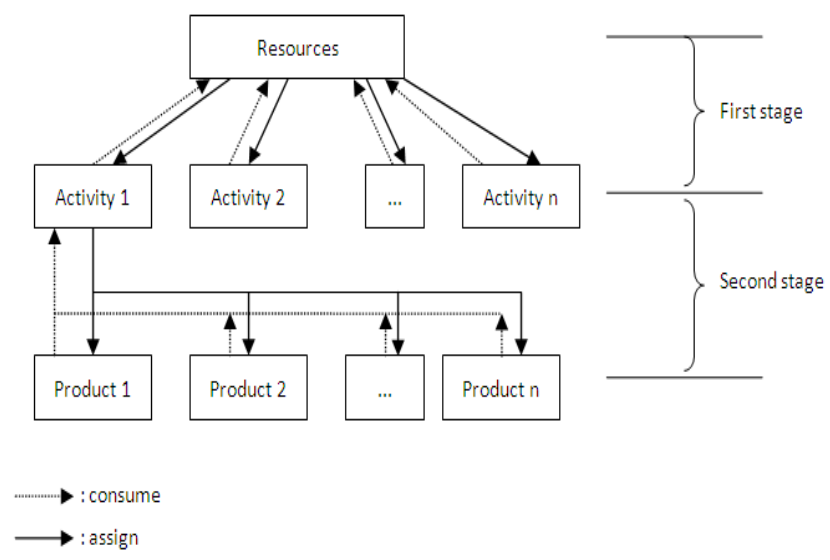

Source: Adapted from Kaplan and Atkinson, 1998

Figure 1: Basic Activity-Based Costing model

In the figure 1, we only draw the consumption from products to activity 1 and assignment cost of acitivity 1 to products as an illustration. Other activities will be made the same as activity 1 .

Increasing the accuracy of product costs in order to provide proper cost information for managers to have a high level of confidence in cost-based decision is one of the primary purposes of an ABC system. Horngren et al (2007) addressed that one of the most important differences between TC system and ABC systems is the extent of allocation across the value chain. TC systems generally allocate only indirect production costs to the products. These are the only costs that can be added to the inventory value of a product for financial reporting purposes, and TC systems often focus on simply measuring such inventory values. They normally do not allocate the cost of other value-chain functions because these are not appropriate costs to include in inventory. $\mathrm{ABC}$ systems, in contrast, focus on the costs that are important to decision makers. They often expand allocation of costs beyond production to processes such as design, marketing, order processing, and customer service. As a result, $\mathrm{ABC}$ systems are more complex than TC systems but promise more accurate and useful costs to aid decision making.

Although ABC systems are rather complex and costly to implement, more and more organizations in both manufacturing and non-manufacturing industries are adopting $\mathrm{ABC}$ systems for variety of reasons (Horngren et al (2007)

1. Fierce competitive pressure has resulted in shrinking 
profit margins. Companies may know their overall margin, but they often do not have confidence in the accuracy of the margins for individual products or services. Some are winners and some are losers - but which ones? Accurate costs are essential for answering this question.

2. Greater diversity in types of products and services as well as customer classes results in greater business operating complexity. Therefore the consumption of a company's shared resources also varies substantially across products and customers.

3. New production techniques have increased the proportion of indirect costs. That is, indirect coats are far more important in today's world - class manufacturing environment than they have been in the past. In many industries automated equipment is replacing direct labor.

4. The rapid pace of technological change has shortened product life cycles. Hence companies do not have time to make price or cost adjustments once they discover costing errors.

5. The costs associated with bad decisions that result from inaccurate cost determinations are substantial.

6. Computer technology has reduced the costs of developing and operating $\mathrm{ABC}$ systems.

Hansen et al (2003) presented that design steps for an ABC system included six steps as follow: (1) Identify, define, and classify activities and key attributes, (2) Assign the cost of resources to activities, (3) Assign the cost of secondary to primary activities, (4) Identify cost objects and specify the amount of each activity consumed by specific cost object, (5) Calculate primary activity rate, (6) Assign activity cost to cost object.

The advantages and limitation of $\mathrm{ABC}$ method have been researched by many researchers as well as academic. Prior researchers agreed that $\mathrm{ABC}$ method have many advantages than traditional costing (TC) method. ABC has been applied in various organizations from profit organizations such as manufacturing, commercial, wholesale and retail, and service to nonprofit organizations such as hospital, university, Government agencies etc. It has been applied not only in large scale companies but also in Small and Medium-sized Enterprises (SMEs). (see Cooper and Kaplan (1991), Akyol et al (2005), Lewis (1992), Cohen et al (2005), Nassar et al (2011)). Kaplan (1998) presented traditional costing systems are inexpensive to operate, but they lead to large distortions in reporting the cost of activities, processes, products, services, and customers. Consequently, managers may make serious mistakes in decisions made on basis of this information; there is a high cost of errors. ABC system also helps clearly identify the root of costs incurred, the activities consume costs to create values and the activities consume costs but not create values for the business, therefore managers will make the right decision in the operation executive, and continuous improvement of business activities towards higher the value chain. It provides not only accurate financial information but also non-financial for managers at all levels in organization. By providing more accurate and more reliable information than information provided by $\mathrm{TC}, \mathrm{ABC}$ is useful information for decision-making and performance evaluation (see: Nassar et al (2011), Cohen et al (2005), Kevin (2007), Khozein and Dankoob (2011), Zhang and Isa (2010)).

Beside the numerous advantages, ABC still has disadvantages that make difficult to apply it. Kaplan and Anderson (2004) pointed out three disadvantages: the first in order to construct the $\mathrm{ABC}$ model, the companies must collect and analyze costs of many different activities, the second is that $\mathrm{ABC}$ needs more cost-driver than $\mathrm{TC}$, the identification of cost drivers is often complex, the third $\mathrm{ABC}$ requires the personnel ability of employees and managers. Nassar et al. (2011) summarized the reasons for non-implementation by the 45 companies in Jordan, which had not implemented $\mathrm{ABC}$ : lack of local consultants, high cost of $\mathrm{ABC}$ implementation, high cost of consultants, lack of journals, conferences, seminars about ABC in Jordan, lack of accounting bodies, lack of knowledge of $\mathrm{ABC}$ implementation, uncertainty of $\mathrm{ABC}$ benefits, $\mathrm{ABC}$ system is too complex. The lack of local consultants, high cost of $\mathrm{ABC}$ implementation, and the high cost of consultants were cited by the majority of interviewees as the most significant reasons for non-implementation of ABC. Chung et al. (2001) surveyed the status of $\mathrm{ABC}$ implementation in Hong Kong-China pointed out the factors affected $\mathrm{ABC}$ implementation included: insufficient human resources, satisfactory current systems, insufficient information technology, time consuming implementation, lack of top management support, inadequate knowledge. In which lack of adequately trained personnel was cited as a major reason for not adopting ABC. Respondents also believed that implementation would require a significant time involvement. Satisfaction with the existing traditional cost accounting system and lack of support from top-level management were also factors in the decision not to use $\mathrm{ABC}$. Cohen et al (2005), regardless of the numerous benefits of $\mathrm{ABC}$ that are widespread in the literature there are companies that strongly oppose to the possibility of $\mathrm{ABC}$ adoption. According to the findings of relevant researches, the main reasons for rejecting the adoption of $\mathrm{ABC}$ could be summarized by the following reasons: satisfaction with the existing costing system, ABC implementation being associated with high costs, lack of time to undertake an assessment of $\mathrm{ABC}$ implementation, $\mathrm{ABC}$ 's perceived inadequacy to provide more accurate cost information.

\subsection{Economic Value Added}

Most managers agree that measuring return in relation to investment provides the ultimate test of profitability. On popular variant coined and marketed by Stern Stewart \& co. is called economic value added (EVA $\left.{ }^{\mathrm{TM}}\right)$. The $\mathrm{EVA}^{\mathrm{TM}}$ formula was presented by Hilton (2002) Economic value added (EVA) is after-tax operating income minus the total annual cost of capital with the formula as follow: 
EVA $\quad$ After-tax operat- ing income $-\left(\begin{array}{c}\text { Weight-average } \\ \text { cost of capital }\end{array}\right)\left(\begin{array}{c}\text { Total capital } \\ \text { employed }\end{array}\right)$

Weight-average cost of capital (WACC) is defined as follows:

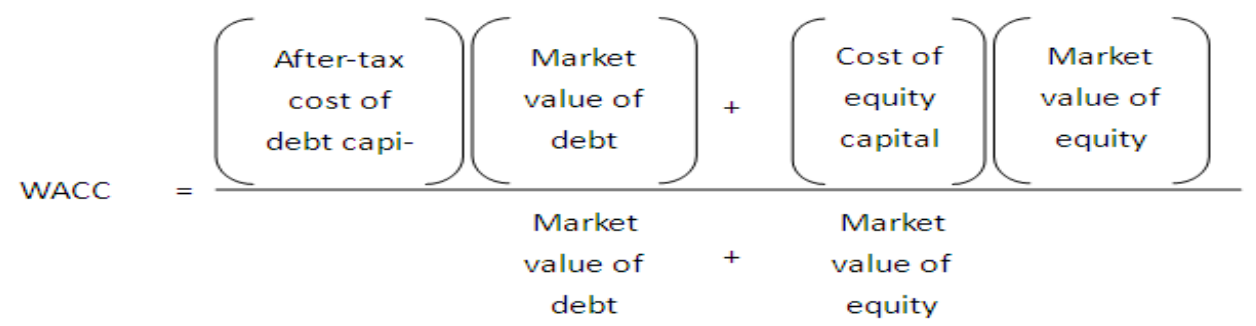

If $\mathrm{EVA}^{\mathrm{TM}}$ is positive, the company is creating wealth, if it is negative, then the company is destroying capital. Over the long term, only those companies creating capital, or wealth, can survive, particularly in today's fiercely competitive business environment. When EVA ${ }^{\mathrm{TM}}$ is used to adjust management compensation; it encourages managers to use existing and new capital for maximum gain. The key feature of $\mathrm{EVA}^{\mathrm{TM}}$ is its emphasis on after-tax operating income and the actual cost of capital. Other return measures may use accounting book value numbers which may or may not represent the true cost of capital.

According to Stewart (1990) EVATM may be viewed as a measure of value as well as a measure of performance. EVA $^{\mathrm{TM}}$ can be used to: set goals, evaluate performance, determine bonuses, communicate with investors, and budget for capital expenditure (Stewart, 1990). Using the EVA ${ }^{\text {TM }}$ measure to assess performance will overcome the inherent limitations of traditional methods of performance measurement such as inventory turnover, return on total asset (ROA), return on equity (ROE), return on investment (ROI), and help managers as well as the investors know the true value is generated from the business performance. In addition, EVA ${ }^{\mathrm{TM}}$ is also best measure to evaluate and reward managers at department levels, help department managers toward to common goals of organization. The last few years have witnessed a tremendous growth in writing on EVA. Printed and web-published lecture notes on the subject abound in the financial press, practitioner publications, and numerous unpublished working papers. The objective of this paper is not to present how EVA ${ }^{\mathrm{TM}}$ works, and how to design and implement EVA, these issues have been well discussed and can be found in many management literatures (Nikhil (2009), Nthoesane (2012), Roztocki et al. (1999), Nthoesane (2012)). According to Nikhil (2009), EVA ${ }^{\mathrm{TM}}$ computation requires six basis steps: (1)Collect and Review Financial Statements; (2)Identify the distortions and adjustments required to make it distortion free; (3) Identify the company's capital structure; (4)Determine the company's weighted average cost of capital (WACC); (5)Calculate the company's Net Operating Profit after Tax, (6) Calculation of Economic Value Added. According to Narcyz and Needy (1999) in their research on how to design and implement an Integrated Activity-Based Costing and Economic Value Added System suggested 6 step for calculate capital charge for cost objects: (1) Review the company's financial information; (2)Identify main activities; (3) Determine the operating cost for each activity; (4) Select cost drivers, (5) Calculate operating costs for cost objects; (6) Calculate capital charges for cost objects.

In our research, we consider capital cost as a kind of cost in business operating. So, it should be assign to activities for calculating the product cost. The framework for $\mathrm{ABC}$ and EVA $^{\mathrm{TM}}$ integrating was shown bellow:

\section{A framework for Integrating ABC with EVA}

As we mentioned above, $\mathrm{ABC}$ theory and $\mathrm{ABC}$ technical lack to focus capital cost lead to shortcoming in provision accurate information for managers make decision. Integrating $\mathrm{ABC}$ system with $\mathrm{EVA}^{\mathrm{TM}}$ to overcome $\mathrm{ABC}$ 's limitation and provide proper and more reliable information for management. On the other hand through the accuracy of $A B C$ 's data to provide details of each activity as a basis for the accurate calculation of $\mathrm{EVA}^{\mathrm{TM}}$ for each project, process or product that helps managers have the right evaluation on the organization efficiency at the lowest level.

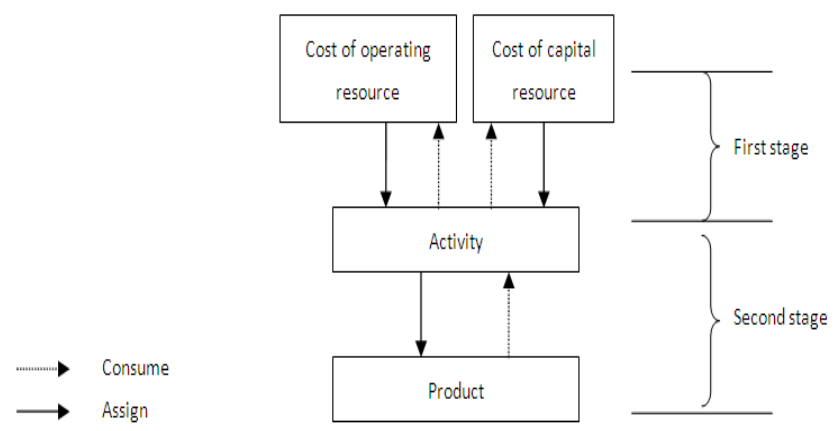

Source: Adapted from Kaplan and Atkinson, 1998

Figure 2: Basic EVA-ABC model 
Economic value added (EVA) is considered as a method measures operating efficiency of an organization. The accuracy of its results depends on the data input for calculating process. As we analyzed above, ABC provides more detailed and more accurate information than traditional costing system, however, $\mathrm{ABC}$ focuses on the operating costs and ignores capital cost. This is one of limitations of $\mathrm{ABC}$. The results of $\mathrm{ABC}$ analysis ignore capital cost needed to produce or provide goods may lead managers have poor decision-making. Some prior researches indicated that in many cases, many organizations have high operating profit for a particular process or product line does not necessarily indicate its generation of wealth for investors. If the actual capital cost is higher than the operating profit, the organization destroys its capital than preserves and develops its one (see Roztocki and Needy (1999), Chiadamrong, (2003)).

As we previously mentioned, capital cost is considered as a kind of cost that business must bear during its operation. Therefore, capital cost should be calculated when we evaluate the operating efficiency of a business. In a business using traditional costing, EVA ${ }^{\mathrm{TM}}$ usually calculated at the business level. This result just provided information for managers at the business level. What happen if the managers just evaluate the operating efficiency at the business level? Managers lack a look insight at the lower level in business. At the business level, EVA ${ }^{\mathrm{TM}}$ is positive but at lower level, for example, process, activity or product, some EVA ${ }^{\mathrm{TM}}$ value at lower level maybe is negative. We can see simple illustration bellow in order to have an overview of the role of $\mathrm{ABC}$ and $\mathrm{EVA}^{\mathrm{TM}}$ integration (EVA-ABC).
We apply EVA-ABC to analyze the operating efficiency and financial statement of Dong $\mathrm{Su}$ enterprise. Dong $\mathrm{Su}$ consultants tax and do accounting for Small and Medium Enterprises. It mainly serves two group customers. Group 1 includes service, and trading companies, group 2 includes manufacturing companies. The business unit income Statement as follow:

Table 1: Business Unit income Statement

\begin{tabular}{ccc}
\hline & Income Statement & $\%$ \\
\hline Sales & $2,000,000,000$ & $100 \%$ \\
Cost of service & $1,250,000,000$ & $63 \%$ \\
Gross Margin & $750,000,000$ & $38 \%$ \\
Admin. Expense & $350,000,000$ & $18 \%$ \\
Operating profit & $400,000,000$ & $20 \%$ \\
Capital employed & $1,500,000,000$ & $75 \%$ \\
Capital charge (10\%) & $150,000,000$ & $8 \%$ \\
Economic Value Added & $250,000,000$ & $13 \%$ \\
\hline
\end{tabular}

Source: Data provided by Dong Su Financial Taxable Consulting Co., Ltd

At the business level, EVA value is positive; Dong $\mathrm{Su}$ generated an increase in its capital. However, managers just have a look the financial statement at the business level, lack of detailed information about what customer group created value for company and what one destroyed its capital. By using EVA-ABC, managers have a look insight in detailed of value generated by customer groups. The result was shown on table 2 as bellow.

Table 2: EVA-ABC income statement (at customer group level)

\begin{tabular}{|c|c|c|c|c|c|c|}
\hline & \multicolumn{2}{|c|}{ Business Unit } & \multicolumn{2}{|l|}{ Group 1} & \multicolumn{2}{|l|}{ Group 2} \\
\hline & $\begin{array}{c}\text { Income Statement } \\
\text { (VND) }\end{array}$ & $\%$ & $\begin{array}{c}\text { Income Statement } \\
\text { (VND) }\end{array}$ & $\%$ & $\begin{array}{c}\text { Income Statement } \\
\text { (VND) }\end{array}$ & $\%$ \\
\hline Sales & $2,000,000,000$ & $100 \%$ & $1,200,000,000$ & $100 \%$ & $800,000,000$ & $100 \%$ \\
\hline Cost of service & $1,250,000,000$ & $63 \%$ & $650,000,000$ & $54 \%$ & $600,000,000$ & $75 \%$ \\
\hline Gross Margin & $750,000,000$ & $38 \%$ & $550,000,000$ & $46 \%$ & $200,000,000$ & $25 \%$ \\
\hline Admin. Expense & $350,000,000$ & $18 \%$ & $180,000,000$ & $15 \%$ & $170,000,000$ & $21 \%$ \\
\hline Operating profit & $400,000,000$ & $20 \%$ & $370,000,000$ & $31 \%$ & $30,000,000$ & $4 \%$ \\
\hline Capital employed & $1,500,000,000$ & $75 \%$ & $600,000,000$ & $50 \%$ & $900,000,000$ & $113 \%$ \\
\hline Capital cost $(10 \%)$ & $150,000,000$ & $8 \%$ & $60,000,000$ & $5 \%$ & $90,000,000$ & $11 \%$ \\
\hline EVA-ABC profit & $250,000,000$ & $13 \%$ & $310,000,000$ & $26 \%$ & $(60,000,000)$ & $-8 \%$ \\
\hline
\end{tabular}

Source: Data provided by Dong Su Financial Taxable Consulting Co., Ltd

Note: the costs divided to group1 and group2 were done by $\mathrm{ABC}$ component, and capital cost was calculated by EVA $^{\mathrm{TM}}$ component as we previously mentioned in formula (1) and (2). In this illustration, we assumed WACC $=10 \%$, in fact WACC is calculated by the formula (2).

When we used EVA-ABC analysis, the problem arises from group 2. In order to serve this group Dong Su must recruit good accountants with higher salary, using high speed processing computer, and the software that must include cost calculation program. Lead to investment large amount and expensive assets for this group. Additional, the time spends to consult for manufacturing companies are many times larger than for a service or trade companies.

By driving EVA $^{\mathrm{TM}}$ from a business unit level down to activities and calculating individual customer group, EVA ${ }^{\mathrm{TM}}$ gives managers far more leverage to increase total EVA ${ }^{\mathrm{TM}}$ 
for the unit. Instead of using a meat-cleaver, managers can apply a surgical scalpel to the particular activities and to individual customers that causes negative EVA (group 2). It helps managers have better decision by increasing the output service price and find the best way to cut the waste. The component of $\mathrm{ABC}$ help managers find out non-value-added activities, and reveal opportunities for eliminating them. The integrating the ideas of $\mathrm{EVA}^{\mathrm{TM}}$ and $\mathrm{ABC}$ create a new method for managers make better decision and becomes sensitive to the economic return of products, customers, and channels. It also helps managers assign the resource and capital more efficient in use.

\section{Conclusion}

In this paper, an attempt has been made to present the background of $\mathrm{ABC}$ and $\mathrm{EVA}^{\mathrm{TM}}$ integration. EVA-ABC focuses on both operation costs and capital costs at lower level. It gives managers a comprehensive view of the costs used by each activity allocated to products. Under EVA-ABC, top managers can accurately assess operating efficiency and the responsibility of managers at all levels of their business.

$\mathrm{ABC}$ method single allocates accurately indirect costs for calculating cost of the individual products and provides reliable information for management to make right decisions is very important in today's global competitive environment. Integrating $\mathrm{ABC}$ with $\mathrm{EVA}^{\mathrm{TM}}$ helps managers not only to solve the matters involved indirect costs, to realize value-added activities and non-value-activities but also help managers to know capital cost charge to activities. Under EVA-ABC managers have a look insight in financial picture and operating efficiency at the lowest level, help managers properly evaluate what kind of products to create value for companies and what products decline its capital. Managers are alerted that there must be problems requiring attention at a particular product when the profit calculated by EVA-ABC is negative number. As illustrated in table 2 EVA-ABC provided detailed information to managers on each customer group. The managers must find the appropriate solutions for the problems that group 2 have. For example, managers can find non-value-activities to limit them for reducing service costs or discuss them with customers for increasing service price.

EVA-ABC method is very useful strategic managerial tool; it has the potential to help managers improve the business performance by giving them a better understanding of the true and full costs and the root causes that generated the value for the organization or that destroyed its capital. This approach is not only help managers understand capital cost in company is a treasured resource that has to be used effectively but also provide a more comprehensive information for planning, making and control decisions that can be exploited to maximize the business's economic income.

In the scope of this article, the focus is on building and discussing EVA-ABC method and it also focus on full cost than $\mathrm{ABC}$ single. The only shortcoming of EVA-ABC is that lacks to discuss standard cost or target cost. Further research will be done to join together EVA-ABC method with other management accounting methods such as standard costing or target costing. This gives a perfect method for managers to run control and make accurate decision in their organizations.

\section{Acknowledgements}

We would like to thank Professor Guang Ming. Gong leader of Business School of Hunan University and PhD. Dong Su Financial Taxable Consulting Co., Ltd. Finally we thank to all authors that our paper cited.

\section{References}

[1] Akyol, D.E., Tuncel, G. and Bayhan, G.M., 2005. A comparative analysis of activity-based costing and traditional costing. World Academy of Science, Engineering and Technology, 3, 44-47.

[2] Cohen, S., Venieris, G. and Kaimenaki, E., 2005. ABC: adopters, supporters, deniers and unawares. Managerial Auditing Journal, 20(9), 981-1000.

[3] Cooper, R. and Kaplan, R.S., 1991. Profit priorities from activity-based costing. Harvard Business Review, May-June, 130-135.

[4] N. Chiadamrong, 2003. Integrating abc and eva to evaluate investment decisions. AJSTD, 20 (1), 87-95.

[5] Hansen, D.R. and Mowen, M.M., 2003. Cost Management: Accounting and Control. Peking: Peking University Press.

[6] Hilton Ronald W., 2002. Managerial accounting - creating value in a dynamic business environment. China Machine Press.

[7] Horngren, Charles T., Sundem Gary L., Stratton William O. Introduction to management accounting. Peking University Press, 2007.

[8] Kaplan, R.S. and Atkinson, A.A., 1998. Advanced Management Accounting. Prentice Hall International, Inc.

[9] Kaplan, R.S. and Anderson, S., 2004. Time-Driven Activity-Based costing. Harvard Business Review, 2004, November, 1-9.

[10] Kevin Baird, 2007. Adoption of activity management practices in public sector organizations, Accounting and Finance, 47, 551-569.

[11] Khozein, A. and Dankoob, M., 2011. Activity Based Costing System and its Succeed Implementing in Organizations. Australian Journal of Basic and Applied Sciences, 2011, 5(10), 613-619.

[12] Lewis, L.D., 1992. Activity-Based Costing: A Tool for Management. Central Business Review, 11(2), 28-30.

[13] Nassar, M., Al-Khadash, H.A. and Sangster, A., 2011. The diffusion of activity-based costing in Jordanian industrial companies. Qualitative Research in Accounting \& Management, 8(2), 180-200. 
[14] Nikhil Chandra Shil, 2009. Performance Measures: An Application of Economic Value Added. International Journal of Business and Management, 4(3), 169-177.

[15] Nthoesane, Meiya G., 2012. The development of a value creating competencies index: The economic value added (EVA) approach. African Journal of Business Management, 6(10), 3562-3569.

[16] Roztocki, N., \& Needy, K. L., 1999. How to Design and Implement an Integrated Activity-Based Costing and Economic Value Added System. Proceedings from the Industrial
Engineering research '99 Conference.

[17] Stewart, G. B., 1990. The Quest for Value: the EVA management guide, Harper Business, New York.

[18] Zhang, Y.F. and Isa, C.R., 2010. Behavioral and organizational variables affecting the success of $A B C$ success in China. African Journal of Business Management, 4(11), 2302-2308. 